\title{
Penerapan Model Pembelajaran Bahasa Berbasis Tugas (TBLT) dan Materi Otentik dalam Pembelajaran Reading Comprehension di SMA Negeri 2 Kota Ternate
}

\author{
Sutisno Adam ${ }^{1}$, Sulmi Magfirah ${ }^{2}$ \\ ${ }^{1}$ sutisno@unkhair.ac.id, ${ }^{2}$ sulmi@unkhair.ac.id \\ ${ }^{1,2}$ Universitas Khairun
}

\begin{abstract}
Conventional Learning Model, such as lecturing method, which makes teacher as the learning center without notice to the activeness and participation of students in the classroom still, becomes teachers' favorite style in teaching reading comprehension. Consequently, the learning process tends to be monotonous. This factor can answer the reason why the students' achievement in reading skill at SMA 2 Ternate is not optimal. Then, this is suspected to be a factor in the occurrence of these problems. Therefore, the researcher applied TBLT (Task Based Language Teaching) and combine it with authentic material in reading comprehension. This research is a quasi-experimental research with the nonequivalent pretest-posttest group design. The total population of this study were students of XI SMA Negeri 2 Ternate, who were class XI students of SMA Negeri 2 Kota Ternate. One of the XI classes was used as the experimental class and another one became the control class, then it analyzed by using SPSS 20.0. The selection of the class was based on the observation to see the similarity of students' abilities in these classes. The result showed that the TBLT method combined with the authentic material in the Reading Comprehension could increase: (1) the learning motivation of XI SMA 2 Ternate students; (2) increasing the student learning outcomes. It can be seen from the results of the Paired Sample t-test table that the significance $=0.000$ is less than the significant level $(\alpha)=$ 0.05 , then $\mathrm{H} 0$ is rejected. Therefore, it can be concluded that there has been an increasing of learning outcomes in the experimental class from pre-test to post-test. Based on the result, the TBLT method can be recommended as a method used to increase English learning motivation.
\end{abstract}

Keywords: TBLT, Authentic Material, Reading Comprehension

Abstrak: Model pembelajaran konvensional, seperti metode ceramah yang menjadikan guru sebagai pusat pembelajaran tanpa memerhatikan keaktifan dan partisipasi siswa di dalam kelas masih menjadi metode favorit para guru dalam mengajar reading comprehension. Akibatnya, proses pembelajaran cenderung monoton. Faktor ini bisa menjawab kenapa prestasi sisw adalam keterampilan membaca khususnya reading comprehension di SMA Negeri 2 Kota Ternate belum maksimal. Hal ini disebabkanoleh proses pembelajaran di kelas cenderung monoton. Hal ini ditenggarai sebagai factor terjadinya permasalahan tersebut. Oleh karena itu, peneliti akan menerapkan sebuah model pembelajaran bahasa yang berbasis tugas(Task Based Language Teaching) yang selanjutnya disingkat TBLT dan memadukannya dengan materi otentik dalam pembelajaran reading comprehension. Peneltian yang dilakukan ini merupakan penelitian eksperimen semu(quasi experiment) dengan the non equivalent pretest-posttest group design. Total seluruh populasi dari penelitian ini adalah siswa kelas XI SMA Negeri 2 Kota Ternate, yang merupakan siswa kelas XI SMA Negeri 2 Kota Ternate. Salah satu kelas XI dijadikan kelas eksperimen dan salah satu lagi menjadi kelas control, selanjutnya dianalisis menggunakan SPSS 20.0. Pemilihan kelas ini berdasarkan hasil observasi melihat kesamaan kemampuan siswa pada kelas-kelas tersebut. Hasil penelitian menunjukkan bahwa, metode TBLT dan dipadukan dengan materi otentik pada pelajaran Reading Comprehension dapat meningkatkan : (1) motivasi belajar siswa XI SMA 2 Kota Ternate; (2) meningkatkan hasil belajar siswa, dapat dilihat dari hasil tabel Paired Sample t-test diperoleh signifikansi $=0,000$ 
kurang dari taraf signifikan $(\alpha)=0,05$, maka HO ditolak. Sehingga dapat disimpulkan terjadi peningkatan hasil belajar kelas eksperimen dari pre-test ke post-test. Atas dasar tersebut diatas, metode TBLT dapat direkomendasikan sebagai metode yang digunakan untuk meningkatkan motivasi belajar dalam Bahasa Inggris.

Kata Kunci: TBLT, material autentik, Pemahaman membaca

\section{PENDAHULUAN}

Model pembelajaran konvensional, seperti metode ceramah yang menjadikan guru sebagai pusat pembelajaran tanpa memerhatikan keaktifan dan partisipasi siswa di dalam kelas masih menjadi metode favorit para guru dalam mengajar reading comprehension. Akibatnya, proses pembelajaran cenderung monoton. Faktor ini mungkin bisa menjawab kenapa prestasi siswa dalam keterampilan membaca khususnya reading comprehension tidak meningkat. Padahal dalam proses belajar mengajar, dibutuhkan kreatifitas dan inovasi dari guru dalam menerapkan sebuah model pembelajaran yang dapat membuat pembelajaran bahasa berjalan secara maksimal.

Sehubungan dengan permasalahan tersebut, peneliti menerapkan sebuah model pembelajaran bahasa yang berbasis tugas (Task Based Language Teaching) yang selanjutnya disingkat TBLT. TBLT merupakan pembelajaran bahasa yang berfokus pada penggunaan tugas yang bersifat mendidik dan melibatkan siswa dalam memahami, memanipulasi, memproduksi atau berinteraksi dalam bahasa target dimana pendekatan lebih menitikberatkan pada pemahaman dari pada bentuk. Selain itu, model pembelajaran berbasis tugas pada penelitian kali ini akan dipadukan dengan materi autentik yang diadopsi dari berbagai sumber seperti surat kabar, internet, dan juga majalah.

Pemilihan TBLT pada penelitian ini berdasarkan pertimbangan bahwa (1) dalam penerapan TBLT, siswa dituntut untuk lebih kreatif dan aktif dalam menggunakan keterampilan bahasa yang dikuasinya. Menurut Brandon (2010), TBLT mensyaratkan pembelajar lebih aktif dan memiliki peran utama dalam pembelajaran. (2) pemberian tugas instruksional yang bervariasi baik di dalam maupun di luar kelas dapat meningkatkan kesempatan bagi siswa mengaplikasikan bahasanya diberbagai situasi karena tugas yang diberikan berkaiatan langsung dengan kehidupan sehari-hari. (3) selain itu, tugas yang diberikan juga akan mengaktifkan pengetahuan keterampilan membaca mereka (background knowledge on reading comprehension). 
Adapun alasan memadukan TBLT dengan materi autentik karena materi autentik memiliki banyak manfaat ketika diterapkan di kelas yaitu: asli, menarik, memotivasi dan bermanfaat (Peacock, 1997). Hal ini sejalan Melvin dan Stout (1987) yang menyatakan bahwa menerapkan bahan otentik dapat meningkatkan motivasi siswa untuk belajar bahasa asing dan minat mereka dalam materi pelajaran. Selain itu, mereka mengkonfirmasi bahwa siswa tersebut mendapatkan lebih banyak kepercayaan diri ketika mereka bekerja dengan bahan otentik.

Dengan pertimbangan tersebut, penerapan model pembelajaran bahasa berbasis tugas yang dipadukan dengan materi autentik diasumsikan dapat meningkatkan hasil belajar siswa dalam pengajaran bahasa inggris khususnya reading comprehension. Walaupun demikian, dibutuhkan adanya bukti lapangan dari hasil penerapan TBLT berpaduan materi autentik guna meyakinkan semua guru untuk menerapkan model pembelajaran tersebut dalam pengajarannya. Untuk itu dirumuskan penelitian dengan judul, "Penerapan Model Pembelajaran Bahasa Berbasis Tugas dan Materi Autentik dalam Pembelajaran Reading comprehension di SMA Negeri 2 Kota Ternate"

Berdasarkan latar belakang tersebut dapat dirumuskan beberapa masalah yang menjadi pijakan peneliti dalam melakukan penelitian, yaitu: (1) Apakah hasil belajar reading comprehension siswa dapat ditingkatkan setelah mengikuti pembelajaran melalui model pembelajaran Bahasa berbasis tugas (TBLT) dipadukan materi otentik, (2) Apakah siswa termotivasi mengikuti pembelajaran reading comprehension melalui model pembelajaran berbasis tugas (TBLT) dipadukan materi otentik.

Kemudian, penelitian ini memiliki tujuan sebagai berikut; (1) Meningkatkan hasil belajar reading comprehension siswa melalui model pembelajaran berbasis tugas (TBLT) dipadukan materi otentik, dan (2) Memotivasi siswa mengikuti pembelajaran reading comprehension melalui model pembelajaran berbasis tugas (TBLT) dipadukan materi otentik.

Guru memerlukan model pembelajaran bahasa yang lebih inovatif yang dapat meningkatkan keaktifan siswa di dalam kelas dan membuat pembelajaran terpusat pada siswa juga dibutuhkan materi yang dapat membuat siswa . akhirnya, capaian belajar dan motivasi siswa dalam pembelajaran reading comprehension akan meningkat. Model pembejaran tersebut adalah model pembelajaran berbasis tugas (TBLT) dipadukan materi otentik. Penerapan model ini diasumsikan dapat meningkatkan capaian belajar dan motivasi siswa dalam pembelajaran reading comprehension. 


\section{METODE PENELITIAN}

Jenis penelitian ini adalah penelitian eksperimen semu (quasi experiment). Penelitian eksperimen semu ini dilakukan untuk mengetahui pengaruh suatu perlakuan terhadap karakteristik subjek yang diteliti oleh tim peneliti. Penelitian jenis ini dipilih karena tidak memungkinkan untuk mengontrol semua variabel yang relevan. Sehingga, penelitian ini bertujuan untuk mengetahui efektivitas model pembelajaran bahasa berbasis tugas dipadukan materi otentik pada pelajaran reading comprehension.

Adapun desain penelitian yang akan diterapkan pada penelitian ini adalah the nonequivalent pretest-posttest group design. Berdasarkan hal tersebut, langkah pertama yang dilakukan adalah menentukan kelompok eksperimen dan kontrol. Selanjutnya, memberikan pretest (tes awal) yang sama pada kelompok eksperimen dan kelompok kontrol. Kemudian, kedua kelompok tersebut diberikan perlakuan yang berbeda, yaitu pembelajaran bahasa berbasis tugas dipadukan materi otentik pada kelompok eksperimen sedangkan model pembelajaran kooperatif pada kelompok control. Setelah itu, kedua kelompok diberikan post-test (tes akhir) yang sama. Desain penelitian dapat dilihat pada Tabel 3.1. dibawah ini :

Tabel 1. Desain Penelitian

\begin{tabular}{|c|c|c|c|}
\hline Kelas & Pre-test & Perlakuan & Post-tes \\
\hline $\mathbf{E}$ & $\mathrm{O}_{1}$ & $\mathrm{X}_{1}$ & $\mathrm{O}_{2}$ \\
\hline $\mathbf{C}$ & $\mathrm{O}_{1}$ & $\mathrm{X}_{2}$ & $\mathrm{O}_{2}$ \\
\hline
\end{tabular}

Keterangan:

$\mathrm{E}=$ Kelompok Eksperimen

$\mathrm{C}=$ Kelompok Kontrol

$\mathrm{O}_{1}=$ Pre-test

$\mathrm{X}_{1}=$ Perlakuan / Pembelajaran berbasis tugas dipadukan materi otentik

$\mathrm{X}_{2}=$ Perlakuan / Pembelajaran kooperatif

$\mathrm{O}_{2}=$ Post-tes

(Gay, et al. 2006)

Variabel penelitian terdiri dari variabel bebas (independent), variable terikat (dependent), dan variabel asing (extraneous). Variabel bebas dalam penelitian ini adalah perlakuan yang diberikan pada kelompok eksperimen yaitu model pembelajaran bahasa berbasis tugas (TBLT) dipadukan materi otentik. sedangkan variabel terikat adalah capaian belajar reading comprehension siswa. Capaian pembelajaran merupakan karakteristik subjek yang diukur melalui data pretes dan posttes. Adapun yang menjadi variabel asing adalah motivasi siswa dalam belajar reading comprehension. 
Penelitian ini dilaksanakan di SMA Negeri 2 Ternate yang berlokasi di Kota Ternate Maluku Utara. Waktu pelaksanaan penelitian yaitu pada Bulan April s.d. September. Populasi dalam penelitian ini adalah seluruh siswa kelas XI di SMA Negeri 2 Kota Ternate tahun ajaran 2019/2020. Pengambilan sampel melalui metode cluster sampling yaitu mengambil sampel berupa kelas-kelas. Hal ini dilakukan, karena pemilihan sampel di sekolah hanya bisa dilakukan dengan memilih kelas-kelas yang kemudian dijadikan sebagai kelompok eksperimen. Salah satu kelas XI nantinya akan dijadikan kelas eksperimen dan salah satu lagi akan menjadi kelas control. Pemilihan kelas ini berdasarkan hasil observasi melihat kesamaan kemampuan siswa pada kelas-kelas tersebut.

Data yang telah dikumpulkan dari tes reading comprehension selanjutnya akan dianalisis menggunakan prosedur berikut: Setiap jawaban siswa yang benar akan mendapatkan poin sepuluh dan jawaban salah mendapatkan poin nol. Rumus untuk mengidentifikasi nilai sebagai berikut:

$$
\text { Skor }=\frac{\text { Jumlah jawaban benar }}{\text { Skor maksimum }} \times 100
$$

(Depdiknas dalam Hasriani, 2013)

Selanjutnya, Klasifikasi skor jawaban siswa. Setelah membuat tabulasi nilai siswa, peneliti mengklasifikasikan nilai siswa berdasarkan tabel skala penilaian berikut:

Tabel 2. Klasifikasi Penilaian Capaian Belajar Reading Comprehension Siswa

\begin{tabular}{|c|c|c|}
\hline No & Skor & Klasifikasi \\
\hline 1 & $86-100$ & Sangat Baik \\
\hline 2 & $71-85$ & Baik \\
\hline 3 & $56-70$ & Sedang \\
\hline 4 & $41-55$ & Rendah \\
\hline 5 & $<40$ & Sangat Rendah \\
\hline
\end{tabular}

(Depdiknas dalam Hasriani, 2013)

Menghitung skor rata-rata, standar deviasi, nilai t-test, dan perbedaan yang signifikan antara pretest dan posttest. Semua hal tersebut dianalisis menggunakan Statistical Product and Service Dolution (SPSS) program versi 20.0. Untuk data yang diperoleh dari kuisioner, selanjutnya juga akan dianalisis menggunakan SPSS program versi 20.0. 


\section{HASIL DAN PEMBAHASAN}

Penelitian ini adalah penelitian kuasi eksperimen yang dilakukan di SMA Negeri 2 Kota Ternate. Populasi dalam penelitian ini terdiri dari siswa-siswa kelas XII IPA. Penentuan sampel penelitian pada populasi kelas XII yaitu terdiri atas 40 siswa dilakukan dengan teknik random sampling. Subjek penelitian yaitu siswa kelas XII IPA ${ }^{1}$ sebagai kelompok eksperimen dan kelas XII IPA $^{2}$ sebagai kelompok kontrol. Penelitian ini menggunakan pendekatan deskriptif kuantitatif. Hasil penelitian ini dideskripsikan dengan kata-kata dan angka-angka. Kemudian, teknik pengumpulan data dilakukan dengan melakukan pre-test dan post-test. Sehingga, hasil belajar dilihat dari hasil post-test kelas eksperimen.

Berikut adalah deskripsi pengajaran pada kelas eksperimen dan kelas kontrol. Dalam penelitian ini terlebih dahulu tim peneliti memberikan pre-test pada kelas kontrol maupun kelas eksperimen. Setelah itu, peneliti memberikan perlakuaan atau treatment pada kelas eksperimen. Peneliti sebagai eksekutor mengajar pada siswa kelas ekspreimen dalam 3 kali pertemuan 3 x 90 menit. Pertemuan pertama yaitu peneliti membagikan soal pretest untuk dikerjakan oleh siswa kelas eksperimen dan kelas kontrol kepada 40 siswa. Selanjutnya,di pertemuan kedua peneliti memberikan materi Authetentic Reading pada kelas ekperimen, dan pada kelas kontrol peneliti hanya memberikan materi Reading pada umumnya. Setelah memberikan materi, siswa diminta mengerjakan soal-soal yang diberikan peneliti. Soal-soal pada kelas eksperimen menyangkut soal-soal authentic reading seperti membaca majalah, peta (map), brosur, menu makan, dll. Sedangkan pada kelas kontrol, soal-soal reading berupa soal reading TOEFL dan IELTS. Dan pada pertemuan yang ketiga siswa mengerjakan soal posttest dan ditutup dengan evaluasi dari proses belajar mengajar tersebut.

Berdasarkan data yang dikumpulkan, dari temuan penelitian yang telah direkapitulasi kemudian dianalisis untuk mengetahui apakah ada peningkatan hasil belajar siswa pada kelas XII IPA SMA Negeri 2 Kota Ternate. Analisis data ini melalui dua tahap, yaitu ananlisis deskriptif dan analisis kuantitatif. Berikut adalah hasil data penelitian: 


\section{Data Pretest Kelas Eksperimen dan Kelas Kontrol}

Tabel 3. Pretest Kelas Ekperimen

\begin{tabular}{cccc}
\hline Nilai & Klasifikasi & Frekuensi & Frekuensi Relatif $(\%)$ \\
\hline $86-100$ & Sangat Baik & - & - \\
$71-85$ & Baik & 1 & 5 \\
$56-70$ & Sedang & 5 & 25 \\
$41-55$ & Rendah & 6 & 30 \\
$<40$ & Sangat Rendah & 8 & 40 \\
& & 20 & 100 \\
Rata-rata & 50 & & \\
\hline
\end{tabular}

Tabel 4. Pretest Kelas Kontrol

\begin{tabular}{cccc}
\hline Nilai & Klasifikasi & Frekuensi & $\begin{array}{c}\text { Frekuensi Relatif } \\
(\%)\end{array}$ \\
\hline $86-100$ & Sangat Baik & - & - \\
$71-85$ & Baik & - & - \\
$56-70$ & Sedang & 5 & 25 \\
$41-55$ & Rendah & 9 & 45 \\
$<40$ & Sangat Rendah & 6 & 30 \\
& & 20 & 100 \\
\hline
\end{tabular}

Dari tabel di atas dapat dilihat bahwa nilai rata-rata pretest kelompok eksperimen dan kelompok kontrol adalah relatif sama, yaitu 50. Selain itu, tidak ada siswa baik di kelas eksperimen maupun control yang memiliki nilai pretest di atas 86 atau dengan klasifikasi Sangat Baik. Nilai tertinggi kelas eksperimen yaitu pada klasifikasi Baik, dan nilai tertinggi kelas kontrol adalah pada klasifikasi Sedang.

\section{Data Post-test Kelas Eksperimen dan Kelas Kontrol}

Sedangkan, hasil belajar siswa SMA Negeri 2 pada kelompok eksperimen dan kelompok kontrol dalam Pembelajaran Reading Comprehension setelah eksperimen (posttest) dapat dilihat pada tabel di bawah ini: 
Tabel 5. Posttest Kelas Eksperimen

\begin{tabular}{cccc}
\hline Nilai & Klasifikasi & Frekuensi & Frekuensi Relatif (\%) \\
\hline $86-100$ & Sangat Baik & 3 & 15 \\
$71-85$ & Baik & 3 & 15 \\
$56-70$ & Sedang & 7 & 35 \\
$41-55$ & Rendah & 6 & 30 \\
$<40$ & Sangat Rendah & 1 & 5 \\
& & 20 & 100 \\
Rata-rata & 65.25 & & \\
\hline
\end{tabular}

Dari tabel di atas dapat dilihat bahwa terdapat $3(15 \%)$ siswa mendapat nilai dengan klasifikasi Baik dan Sangat Baik, 7 (35\%) siswa mendapat nilai Sedang, 6 (30\%) siswa mendapat nilai Rendah, dan hanya 1 (5\%) siswa mendapat nilai Sangat Rendah. Sedangkan nilai rata-rata Posttest Kelas Eksperimen yaitu 65.25.

Tabel 6. Posttest Kelas Kontrol

\begin{tabular}{cccc}
\hline Nilai & Klasifikasi & Frekuensi & Frekuensi Relatif (\%) \\
\hline $86-100$ & Sangat Baik & - & - \\
$71-85$ & Baik & - & - \\
$56-70$ & Sedang & 6 & 30 \\
$41-55$ & Rendah & 7 & 35 \\
$<40$ & Sangat Rendah & 7 & 35 \\
& & 20 & 100 \\
Rata-rata & 46.75 & & \\
\hline
\end{tabular}

Tabel 4 menunjukkan bahwa pada kelas kontrol, tidak ada siswa yang mendapat nilai dengan klasifikasi Sangat Baik dan Baik. Namun, terdapat 6 (30\%) siswa mendapat nilai dengan klasifikasi Sedang, dan maisng-masing 7 (35\%) siswa mendapat nilai Rendah dan Sangat Rendah. Sedangkan nilai rata-rata nilai posttest kelas kontrol adalah 46.75 .

\section{Hasil Pengujian Kuantitatif}

\section{Uji Normalitas}

Uji Normalitas bertujuan untuk menguji apakah data variabel dependen dan independen mempunyai distribusi normal atau tidak. Data yang baik adalah memiliki distribusi data normal atau mendekati normal. Untuk menguji normalitas, dapat dianalisis dengan menggunakan metode One Sample Kolmogorov Smirnov Test. Kemudian, dasar keputusan adalah jika nilai 
probabilitas t-statistik $>$ Level of Significant $(\alpha)=0,05$, maka model regresi memenuhi asumsi normalitas.

Tabel 7. Tests of Normality

\begin{tabular}{|l|l|r|r|r|r|r|r|}
\hline & & \multicolumn{3}{|c|}{ Kolmogorov-Smirnov $^{\mathrm{a}}$} & \multicolumn{3}{|c|}{ Shapiro-Wilk } \\
\cline { 3 - 8 } & Kelas & Statistic & \multicolumn{1}{c|}{$\mathrm{df}$} & \multicolumn{1}{c|}{ Sig. } & \multicolumn{1}{l|}{ Statistic } & \multicolumn{1}{c|}{ df } & \multicolumn{1}{c|}{ Sig. } \\
\hline Hasil Belajar & Pre test Eksperimen & .250 & 20 & $.200^{*}$ & .918 & 20 & .090 \\
Siswa & Post test Eksperimen & .228 & 20 & $.200^{*}$ & .944 & 20 & .080 \\
& Pre Test Kontrol & .200 & 20 & .035 & .950 & 20 & .166 \\
& Post Test Kontrol & .231 & 20 & .007 & .912 & 20 & .069 \\
\hline
\end{tabular}

Berdasarkan hasil uji normalitas pada tabel di atas dengan One Sample Kolmogorov Smirnov Test terlihat bahwa nilai probabilitas t-statistik > Level of Significant $=0,05$, maka data memenuhi asumsi normalitas. Dengan demikian, maka variabel dependen dan variabel independen mempunyai distribusi normal dan data yang baik yaitu memiliki distribusi data normal atau mendekati normal.

\section{Pengujian Hipotesis (Peningkatan Hasil Belajar)}

Pengujian kelompok siswa yang mendapatkan perlakuan dengan mengaplikasikan Authentic Material (siswa kelas XII IPA ${ }^{1}$ ) terhadap proses pembelajaran memiliki skor rerata yang lebih tinggi dibandingkan dengan kelompok siswa yang dalam proses pembelajarannya tanpa menggunakan treatment. Berikut adalah hasil uji siswa kelas XII IPA ${ }^{1}$ (kelas eksperimen) menggunakan uji-t:

Tabel 7. Paired Samples Test

\begin{tabular}{|c|c|c|c|c|c|c|c|c|c|}
\hline & \multicolumn{5}{|c|}{ Paired Differences } & \multirow[b]{3}{*}{$\mathrm{t}$} & \multirow[b]{3}{*}{$\mathrm{df}$} & \multirow{3}{*}{$\begin{array}{l}\text { Sig. (2- } \\
\text { tailed) }\end{array}$} \\
\hline & & \multirow[b]{2}{*}{ Mean } & \multirow{2}{*}{$\begin{array}{c}\text { Std. } \\
\text { Deviation }\end{array}$} & \multirow{2}{*}{$\begin{array}{l}\text { Std. Error } \\
\text { Mean }\end{array}$} & \multicolumn{2}{|c|}{$\begin{array}{l}\text { 95\% Confidence } \\
\text { Interval of the } \\
\text { Difference }\end{array}$} & & & \\
\hline & & & & & $\begin{array}{ll}\text { Lower } \\
\end{array}$ & Upper & & & \\
\hline Pair 1 & $\begin{array}{l}\text { Pre Test - } \\
\text { Post Test }\end{array}$ & -15.250 & 12.083 & 2.702 & -20.905 & -9.595 & -5.645 & 19 & .000 \\
\hline
\end{tabular}

Berdasarkan tabel Paired Sample t-test diperoleh signifikansi $=0,000$ kurang dari taraf signifikan $(\alpha)=0,05$, maka $\mathrm{H}_{0}$ ditolak. Artinya ada perbedaan yang signifikan antara rata- rata nilai sebelum perlakuan dengan rata- rata nilai sesudah perlakuan. Pada tabet $\mathrm{t}$ diperoleh $\mathrm{t}$ hitung negatif, yaitu - 5,645 yang artinya rata- rata sebelum perlakuan lebih rendah dari pada 
rata rata sesudah perlakuan. Sehingga dapat disimpulkan terjadi peningkatan hasil belajar kelas eksperimen dari pre-test ke post-test.

Dengan demikian, dapat disimpulkan bahwa hipotesis ini dapat diterima, menyatakan bahwa proses pembelajaran yang menggunakan pemebelajaran berbasis tugas dan materi otentik pada mata Reading Comprehension dapat meningkatkan hasil belajar siswa kelas X di SMA Negeri 2 Kota Ternate.

\section{KESIMPULAN}

TBLT (Task Based Language Teaching) adalah penelitian kuasi eksperimen yang dipadukan dengan materi otentik dalam pelajaran reading comprehension yang dilakukan di SMA Negeri 2 Kota Ternate. Terdapat kelas eksperimen dan kelas control dengan menggunakan 2 jenis instrument, tes yang digunakan untuk mengukur hasil bekajar siswa pada pelajaran reading comprehension dan kuisioner untuk melihat motivasi siswa dalam mata pelajaran ini, selanjutnya terdapat langkah-langkah yang dilakukan peneliti yaitu pretest, treatment TBLT dan materi otentik untuk kelas eksperimen, dan posttest. Hasil dari posttest menunjukkan bahwa terdapat peningkatan hasil belajar kelas eksperimen dari rata-rata angka 50 menjadi 65.25, sebaliknya kelas control yang tidak menggunakan metode pembelajaran TBLT dan materi otentik mengalami penurunan pretest posttest nilai rata-rata dari angka 50 menjadi 46.75. Sehingga, metode ini berhasil digunakan untuk meninkatkan motivasi belajar siswa XI SMA 2 Kota Ternate.

\section{DAFTAR PUSTAKA}

Berardo, S.A. 2006. The Use of Authentic Materials in the Teaching of Reading. The Reading Matrix Vol.6. No.2. Page. 60-767.

Cahyono, W. 2011. The Effect of Using Authentic Materials on the Tenth Grade Students' Reading Comprehension Achievement at SMAN 1 Arjasa in the 2012-2013 Academic Year. Unpublished thesis. Jember: Jember University.

Guo, S. 2012. Using Authentic Materials for Extensive Reading to Promote English Proficiency. Taiwan. Canadian Center of Science and Education. Page. 196-206.

Johnson, E.B. 2004. Comprehension process instruction: Creating Reading success in grades $K-3$. New York, NY: The Guilford Press

Kilickaya. F. 2004. Authentic materials and cultural content in EFL classrooms. The Internet TESL Journal, 10 (7). Retrieved November

Melvin, B.S. and Stout, D.S. 1987. Motivating language learners through authentic materials. In: W. Rivers (ed.) Interactive Language Teaching. New York: Cambridge University Press, 44-56. 
Nunan, David. 2004. An introduction to Task-Based Language Teaching. Asia EFL Journal.

Peacock, M. 1997. The Effect of Authentic Materials on the Motivation of EFL Learners in English. Language Teaching Journal. Volume 51 (2).

Richards, CJ \& Rodgers, ST. 2001. Approaches and Methods in Language Teaching. Cambridge: Cambridge University Press

William Grabe and Fredricka L. Stoller. 2013. Teaching and. Researching Reading, Second Edition. New York: Taylor \& Francis.

Willis, Jane. 2006. A Framework for Task- Based Learning. Harlow: Longman. 
